\title{
KEBIJAKAN MEWUJUDKAN KOTA KUDUS SEBAGAI CITY WALK \\ (KOTA RAMAH TERHADAP PEJALAN KAKI)
}

\author{
Nor Hadi, Subarkah dan Suparnyo \\ Email : nooridola@gmail.com, subarkah_sh@yahoo.com,suparnyo@umk.ac.id \\ Fakultas Hukum Universitas Muria Kudus
}

\begin{abstract}
ABSTRAK
Penelitian ini bermasud untuk mengkaji dan mengetahui potensi rencana tata kota kabupaten Kudus apakah mampu mendukung pelaksanaan City Walk. Selain itu juga untuk mengetahui faktor-faktor yang mendukung maupun yang menghambat dalam pembangunan City Walk di Kota Kudus dan solusinya. Penelitian ini merupakan penelitian hukum empiris atau non doktrinal yang bersifat diskriptif. Data yang digunakan adalah data primer dan sekunder. Teknik pengumpulan data yang digunakan dengan tehnik wawancara, kuesioner dan penelitian kepustakaan. Analisis yang digunakan menggunakan analisis data kualitatif dengan model interaktif data. City Walk di Kota Kudus diusulkan di kawasan Jantung Kota tepatnya di Alun-Alun atau Simpang Tujuh ke barat menuju Jalan Sunan Kudus sampai Masjid Menara Kudus ke utara sampai Pasucen, diharapkan tempat tersebut tempat yang ramai dikunjungi oleh wisatawan baik lokal maupun luar daerah. Alun-Alun atau Simpang Tujuh adalah jantung kota berdekatan dengan Kantor Bupati Kudus dan Mall Ramayana sebagai pusat kegiatan masyarakat Kudus baik untuk rekreasi atau untuk sekedar jalan-jalan di Alun-Alun, karena setiap Minggu pagi ada program dari Pemerntah yaitu Car free Day. Hambatan yang paling mendasar adalah sumber dana dan anggaran untuk mewujudkan Kota Kudus mempunyai branding City Walk dan mewujudkan citra Kudus yang ramah lingkungan dengan fasilitas-fasilitas yang mendukung untuk kenyamanan pejalan kaki di area City Walk. Hambatan disekitar menara Kudus tepatnya di Jalan Sunan Kudus selatan Menara Kudus sebagai tempat parkir, becak wisata, ojek wisata dan angkutan wisata, maka harus ada sosialisasi dan penyuluhan kepada pihak-pihak terkait tentang kebijakan mewujudkan City Walk di kawasan tersebut. Solusinya mereka dipindah ke utara Pasucen, sehingga para peziarah jalan kaki dari Masjid Menara Kudus ke arah utara untuk menikmati City Walk.
\end{abstract}

Kata Kunci : Kebijakan Daerah, City Walk, Car Free Day 


\section{PENDAHULUAN}

Secara geografis, Indonesia terletak pada posisi yang strategis karena diapit dua benua dan juga dua samudera. Pada bagian barat laut Indonesia berbatasan dengan Benua Asia, sedangkan pada bagian Tenggara, Indonesia berbatasan dengan Benua Australia. Pada arah barat, wilayah Indonesia berbatasan dengan Samudera Hindia dan sebelah timur laut berbatasan dengan Samudera Pasifik. Batas-batas geografis ini memberi sejumlah pengaruh bagi Indonesia sebagai sebuah Negara dengan kebudayaan yang beragam.

Letak geografis yang strategis ini menunjukkan betapa kaya Indonesia akan sumber daya alam dengan segala flora, fauna dan potensi hidrografis dan deposit sumber alamnya yang melimpah. Sumber daya alam Indonesia berasal dari pertanian, kehutanan, kelautan dan perikanan, peternakan, perkebunan serta pertambangan dan energi.

$$
\text { Pembukaan Undang-Undang }
$$

Dasar Negara Republik Indonesia Tahun 1945 mengamanatkan pembentukan Negara Indonesia ini untuk mencerdaskan kehidupan bangsa mewujudkan suatu masyarakat yang adil dan sejahtera. Salah satu cara untuk mewujudkan keadilan sosial bagi seluruh Indonesia adalah dengan memanfaatkan sumber daya alam yang ada bagi kesejahteraan masyarakat. Pasal 3 ayat (3) Undang-Undang Dasar Negara Republik Indonesia tahun 1945 juga mengamanatkan bahwa bumi, air dan kekayaan alam yang terkandung di dalamnya dikuasai Negara dan dipergunakan sebesar-besarnya untuk kemakmuran rakyat.
Isu lingkungan hidup pertama kali diangkat sebagai sebagai salah satu agenda dalam pertemuan negara-negara dalam ranah hubungan internasional pada tahun 1970-an. Bertepatan dengan diumumkan "Strategi Pembangunan Internasional" bagi Dasawarsa Pembangunan Dunia ke-2 (the second UN Development Decade) yang dimulai pada tanggal 1 Juni 1970. Sidang Umum PBB menyerukan untuk meningkatkan usaha dan tindakan nasional serta internasional guna menanggulangi "proses kemerosotan kualitas lingkungan hidup agar dapat diselamatkan keseimbangan dan keserasian ekologis demi kelangsungan hidup manusia. Hal ini ditandai dengan diselenggarakannya Konferensi Perserikatan Bangsa-Bangsa (PBB) tentang lingkungan hidup pada tahun 1972 di Stockholm, Swedia yang lebih dikenal dengan Stockholm Conference. Hasil konferensi ini lazim disebut dengan Stockholm Declaration, yang melahirkan 26 prinsip/asas dimana Prinsip I Deklarasi Stockholm 1972 : dikatakan "Setiap manusia memiliki hak fundamental atas lingkungan yang sehat dan layak bagi kehidupan" dan "Setiap manusia bertanggung jawab untuk melindungi lingkungan demi kepentingan generasi kini dan mendatang".

Saat ini separuh penduduk dunia bermukim di kawasan perkotaan dan diperkirakan jumlahnya akan meningkat menjadi 70 persen pada tahun 2050. Penduduk suatu kota pada hakekatnya telah mempunyai hasrat untuk selalu berkembang. Sebagaimana diketahui bahwa perkembangan kemajuan diberbagai bidang dewasa ini sangat pesat, sehingga perlu adanya suatu penangganan yang lebih intensif, 
agar kemajuan yang terjadi dapat bermanfaat bagi masyarakat. Perkembanggan kota-kota di Indonesia senantiasa diikuti permasalahan perkotaan yang kompleks, antara lain munculnya rumah-rumah kumuh yang berdampak pada kualitas hidup masyarakat yang tinggal disana serta kualitas lingkungannya. Transportasi yang tidak aman dan tidak nyaman, pencemaran udara, keadaan PKL yang permanen, hunian liar, pelanggaran ketertiban umum merupakan masalahmasalah yang sering muncul. Untuk itu maka dengan tidak hentihentinya, baik pemerintah pusat maupun pemerintah daerah menghimbau agar masalah pembinaan tata kota lebih ditingkatkan.

Pembinaan tata kota di sini diartikan sebagai memberikan pengarahan, bimbingan serta melakukan pengaturan dan pengawasan terhadap pertumbuhan dan perkembangan kota sehingga tercipta keadaan dan kondisi kehidupan dan penghidupan yang memenuhi ketentuan dan persyaratan lingkungan yang bersih, sehat, rapi, indah. Sebab lingkungan-lingkungan yang sehat, rapi dan indah itu tentu menjadi idaman baik bagi masyarakat desa maupun masyarakat kota. Selain itu juga, pembinaan tata kota dimaksudkan untuk menjamin pertumbuhan dan perkembangan kota-kota yang serasi satu dengan yang lainnya dan serasi pula dengan yang menjadi kawasan lingkungannya.

Saat ini banyak kualitas ruang kota kita semakin menurun dan masih jauh dari standar minimum sebuah kota yang nyaman terutama pada penciptaan maupun pemanfaatan ruang terbuka yang kurang memadai. Penurunan kualitas itu antara lain dari tidak ditata dan kurang terawatnya pedestrian atau ruang pejalan kaki, perubahan fungsi taman hijau, atau telah menjadi tempat mangkal aktivitas tertentu yang mengganggu kenyamanan warga kota lain untuk menikmatinya. Demikian pula halnya di Kabupaten Kudus. Pemerintah Kabupaten Kudus berkewajiban mengelola aset kota agar menjadi lebih produktif dan efisien, sehingga akan berdampak pada peningkatan kesehjahteraan masyarakat. Demi menciptakan kualitas tata ruang kota maka Pemerintah Kabupaten Kudus mengeluarkan Peraturan Daerah Kabupaten Kudus Nomor 16 Tahun 2012 Tentang Rencana Tata Ruang Wilayah Kabupaten Kudus Tahun 2012 -2032 .

Masyarakat dalam kehidupannya akan berjalan dengan tertib dan teratur bila ada tatanan, sedangkan tatanan dalam kehidupan manusia mempunyai sifat-sifat yang berlainan. Perbedaan itu karena masing-masing tatanan mempunyai sifat yang tidak sama. ${ }^{37}$ Kehadiran hukum dalam masyarakat untuk mengintegrasikan dan mengkoordinasikan kepentingankepentingan yang bisa bertubrukan satu sama lain, sehingga tubrukan itu bisa ditekan sekecil mungkin. ${ }^{38}$

Negara Indonesia adalah negara hukum tertulis dalam Pembukaan UUD 1945 yaitu melindungi segenap bangsa Indonesia dan seluruh tumpah darah Indonesia, memajukan kesejahteraaan umum, mencerdaskan kehidupan bangsa, dan ikut melaksanakan ketertiban dunia berdasarkan

\footnotetext{
${ }^{37}$ Satjipto Raharjo, Ilmu Hukum, Citra Aditya Bakti, Bandung, 2012, hal.13

${ }^{38}$ Ibid. hal. 53
} 
kemerdekaan, perdamaian abadi dan keadilan sosial. Kemudian dijabarkan secara rinci dalam pasal-pasal UndangUndang Dasar Republik Indonesia 1945 dan dioperasionalkan dalam bentuk undang-undang atau peraturan perundangan yang dibawahnya. ${ }^{39}$ Peraturan perundang-undangan terdiri dari beberapa jenis, yang secara garis besar dapat dibagi menjadi peraturan perundang-undangan di tingkat pusat dan peraturan perundang-undangan di tingkat daerah. Salah satu bentuk peraturan perundang-undangan di tingkat daerah adalah peraturan daerah.

Berdasarkan latar belakang di atas, maka rumusan permasalahan dalam penulisan penelitian ini adalah:

1. Bagaimana potensi Kabupaten Kudus dalam mebangun City Walk di jantung Kota?

2. Apakah faktor-faktor yang mendukung dan menghambat pembangunan City Walk di Kota Kudus ?

3. Bagaimanakah upaya untuk mengatasi hambatan-hambatan dalam pembangunan City Walk di Kota Kudus ?

\section{METODE PENELITIAN}

Metode pendekatan yang digunakan dalam penelitian ini yaitu yuridis empiris, sehingga membutuhkan data primer dan data sekunder untuk menjawab beberapa permasalahan yang ada. Data primer didapatkan melalui wawancara sedangkan data sekunder didapatkan dari bahan-bahan pustaka yang telah ada sebelumnya.

${ }^{39}$ Imam Syaukani, Dasar-Dasar Politik Hukum, PT. Raja Grafindo Persada, Jakarta, 2015, hal.45
Penelitian ini menggunakan spesifikasi penelitian deskriptif analitis, yaitu mendeskripsikan hasil penelitian yang berupa data primer yang diolah dan dianalisis sesuai dengan perangkat peraturan perundang-undangan yang berlaku mengenai tata kota.

\section{HASIL PENELITIAN DAN PEMBAHASAN}

Pemerintah daerah diamanatkan Undang-Undang Nomor 32 tentang Pemerintah Daerah, otonomi daerah sebagai keluasan mengurus kepentingan masyarakat setempat, berdasarkan prinsip-prinsip demokrasi, peran serta masyarakat, prakarsa dan aspirasi masyarakat. ${ }^{40}$ Negara Indonesia adalah Negara Kesatuan yang memberikan otonomi daerah, sedangkan pelaksanaannya telah diatur Undang-Undang Dasar 1945 Pasal 18 ayat 1 ,

"Bahwa wilayah Indonesia terbagi atas daerah-daerah yang bersifat otonom atau adminitratif. Daerah-daerah tersebut mempunyai pemerintahan yang ditetapkan berdasarkan Undang-Undang”

Daerah-daerah otonom dalam menentukan susunan pemerintahannya dengan sistem permusyawaraatan dalam sistem negara dan hak-hak asal usul dalam daerah-daerah yang bersifat istimewa. $^{41}$

Negara kesatuan tanggung jawab pelaksanaan tugas-tugas pemerintahan masih dikuasai oleh pemerintah pusat, akan tetapi di negara Indonesia menganut sistem desentralisasi, maka

\footnotetext{
40 Natak Kristiono, Buku Ajar Otonomi

Daerah, Jurusan Politik dan Kewarganegaraan, Fakultas Ilmu Sosial, Unnes semarang, 2015, hal.3

${ }^{41}$ Ibid. hal.4
} 
ada tugas-tugas tertentu yang diurus sendiri oleh daerah, sehingga ada hubungan timbal balik antara pemerintah pusat dan pemerintah daerah dalam hubungan kewenangan dan pengawasan. ${ }^{42}$ Konsep desentralisasi telah diatur oleh Undang Undang Nomor 32 Tahun 2004 Tentang Pemerintah Daerah. Kemudian dengan Undang-Undang Nomor 23 Tahun 2014 tentang Pemerintahan Daerah dan telah beberapa kali diubah terakhir dengan Undang-Undang Nomor 9 Tahun 2015 tentang Perubahan Kedua Atas UndangUndang Nomor 23 Tahun 2014 tentang Pemerintahan Daerah.

Di dalam Pasal 1 angka 2 Undang-Undang Nomor 23 Tahun 2014 tentang Pemerintahan Daerah (selanjutnya disebut Undang-Undang Pemerintahan Daerah) menyebutkan bahwa Pemerintahan Daerah adalah penyelenggaraan urusan pemerintahan oleh pemerintah daerah dan dewan perwakilan rakyat daerah menurut asas otonomi dan tugas pembantuan dengan prinsip otonomi seluas-luasnya dalam sistem dan prinsip Negara Kesatuan Republik Indonesia sebagaimana dimaksud dalam Undang-Undang Dasar Negara Kesatuan Republik Indonesia Tahun 1945.

Demikian juga pada Pasal 1 angka 3, disebutkan bahwa Pemerintah Daerah adalah kepala daerah sebagai unsur penyelenggara Pemerintahan Daerah yang memimpin pelaksanaan urusan pemerintahan yang menjadi kewenangan daerah otonom. Tugas Pemerintahan Daerah menurut Kaufman yaitu melayani serta mengatur masyarakat, tugas pelayanan

${ }^{42}$ Ibid.hal.5 menekankan pada upaya Pemerintah untuk mendahulukan kepentingan umum, memberikan pelayanan publik dengan baik sehingga publik puas dengan pelayanan oleh Pemerintah. Tugas mengatur menekankan pada kekuasaan (power) yang melekat pada pejabat birokrasi. ${ }^{43}$

\section{Kebijakan Daerah}

Konsep kebijakan atau dalam bahasa Inggris sering digunakan dengan istilah policy. Kamus Besar Bahasa Indonesia, istilah kebijakan diartikan sebagai rangkaian konsep dan asas yang menjadi garis besar dan dasar rencana dalam pelaksanaan suatu pekerjaan, kepemimpinan, dan cara bertindak (tentang pemerintahan, organisasi, dsb); pernyataan cita-cita, tujuan, prinsip dan garis pedoman untuk manajemen dalam usaha mencapai sasaran.

Thomas $\mathrm{R}$ Dye sebagaimana dikutip Islamy 44 mendefinisikan kebijakan publik sebagai "is whatever government chooseto do or not to do" (apapaun yang dipilih pemerintah untuk dilakukan atau untuk tidak dilakukan). Definisi ini menekankan bahwa kebijakan publik adalah mengenai perwujudan "tindakan" dan bukan merupakan pernyataan keinginan pemerintah atau pejabat publik semata.

\section{Tipologi City Walk sebagai Ruang Terbuka}

Ruang terbuka publik merupakan ruang wadah aktivitas sosial yang

\footnotetext{
43 Kaufman, Tugas dan Tanggungjawab Pemerintahan, Refika Aditama, Jakarta, 2011, hal. 25

44 Irfan Islami, Prinsip-Prinsip Perumusan Kebijakan Negara, PT. Bumi Aksara, Jakarta, 2002, hal. 20
} 
melayani dan juga mempengaruhi kehidupan masyarakat kota. Ruang terbuka juga merupakan wadah dari kegiatan fungsional maupun aktivitas ritual yang mempertemukan sekelompok masyarakat dalam rutinitas normal kehidupan sehari-hari maupun dalam kegiatan periodik. Dengan adanya pertemuan dan aktivitas bersama antar manusia, kemungkinan akan timbul bermacam-macam aktifitas yang terjadi di ruang tersebut. Dasarnya ruang terbuka merupakan ruang kota mudah dicapai oleh semua orang dan terkesan terbuka sehingga pengaruh dari alam misalnya : angin, matahari, suara, dan air hujan masih dapat dirasakan.

\section{City Walk sebagai Fungsi Komersil}

Kegiatan komersial merupakan wadah kegiatan perniagaan, pembelian atau penjualan barang dan jasa khususnya secara besar-besaran baik nasional maupun internasional. Fasilitas Komersial adalah segala yang memudahkan sarana dan prasarana untuk melakukan kegiatan perniagaan atau perdagangan baik itu barang ataupun jasa . Orientasi dari fasilitas komersial lebih kepada keuntungan finansial yang akan dihasilkan dengan adanya pedagang dan kegiatan perekonomian di dalamnya, dengan prinsip ekonomi "pengeluaran sekecilkecilnya untuk memperoleh keuntungan sebesar-besarnya".

\section{Tata Kota Kabupaten Kudus}

Kudus merupakan salah satu kota di pantai utara Jawa yang merupakan salah satu kota yang berkembang karena adanya aktivitas penyebaran agama Islam. Menurut catatan sejarah Kota Kudus didirikan oleh Sunan
Kudus (Ja'far Shodik) pada abad XVI, tanggal 23 September 1549 M yang berdasarkan condro sengkolo yang ada pada mihrab Masjid Menara (Al Aqsha). Pemberian nama Kudus diserap dari bahasa Arab "quds" yang berarti suci, tidak seperti kota-kota lainnya yang diilhami dari Bahasa Jawa. Oleh Sunan Kudus, Kota Kudus didirikan di atas tiga pilar ideologi, ekonomi dan politik kebersamaan tiga ras/suku yang ada yakni Jawa, Arab dan China. Sunan Kudus sendiri mewakili suku arab, dan beliau masih mempunyai keturunan dengan Husein bin Ali. Masyarakat Kudus sebagian besar merupakan suku jawa dan keberadaan suku China diwakili oleh The Ling Sing (Kyai Telingsing) yang merupakan seorang China beragama Islam yang telah datang ke Kudus yang sebelumnya bernama Tajug, sekitar tahun 1400-an. Kyai Telingsing sendiri diperkirakan berasal dari Hunan, Tiongkok selatan yang datang ke Kudus (Tajug) bersama dengan temantemannya yaitu Kyai Ageng Wajah, Kyai Ageng Kedangeyan, dan Nyi Ageng Melati. Bukti keberadaan suku China bisa dilihat dari adanya ukiran burung Hong dan Nagara pada ukiranukiran rumah di Kudus, serta adanya perkampungan China di daerah Kudus Kulon sekitar Pasar Bubar, dekat kompleks Masjid Menara dan adanya klenteng sekitar Masjid Menara yang dianggap sebagai klenteng tertua di Kota Kudus.

Dakwah Sunan Kudus yang menyebarkan agama secara damai dan berakulturasi dengan budaya Hindu yang sebelumnya telah ada menjadi bukti adanya akulturasi dan perpaduan budaya di Kudus sehingga penyebaran agama ini tidak menimbulkan konflik, 
tetapi dikembangkan berdasarkan budaya saling menghormati, hal ini dibuktikan dengan adanya larangan menyembelih sapi dan adanya Menara Kudus, yang merupakan bangunan masjid yang dihiasi oleh ornamen Hindu (Menara dan Gapura). Pada tempat wudlu masjid ini juga dihiasi dengan ornament berbentuk kepala arca yang berjumlah delapan yang merupakan akulturasi dengan Astasanghikanarga yang dalam Agama Budha berjumlah delapan yang diartikan sebagai pengetahuan, keputusan, perkataan, perbuatan, penghidupan, daya usaha, meditasi dan kontemplasi. $^{45}$

Strategi dakwah yang dikembangkan oleh Sunan Kudus mengedepankan jalan hikmah (kebijaksanaan) melalui dua jalur sekaligus, yaitu jalur struktural; dengan terlibat dalam sistem pemerintahan/kesultanan, misalnya pada posisinya sebagai Senopati di Kesultanan Demak dan sebagai pemimpin dan sekaligus pendiri negeri Kudus (balad al Quds). Sementara pada jalur kultural, Sunan Kudus sangat toleran dan menghargai perbedaan latar budaya setempat. Lebih mementingkan isi (substansi) daripada bentuk formal. Hal ini bisa dicermati melalui pelacakan kiprah dakwah Sunan Kudus dalam bentuk; menciptakan ruang budaya yang dijiwai nila-nilai Islam, misalnya bangunan Menara Kudus dan Masjid yang dijiwai semangat multi kulturalisme, menggubah cerita-cerita yang bersifat ketauhidan, pengobatan (spiritual healing), keteladanan

45 Abdul Jalil, Agama Tanpa Konflik, Rakor FKDM Kesbangpol Jateng, 2 Juni 2014. (modeling), serta membangun jaringan yang kuat sesama wali. Dengan demikian Sunan Kudus dalam dakwahnya mengedepankan pentingnya tanda budaya dan ruang simbolik yang Islami namun dengan tidak mengubur habis tradisi lama ${ }^{46}$.

\section{Kebijaan Pemerintah Kota Kudus Mengenai City Walk}

Kebijakan pemerintah untuk mewujudkan City Walk di Kabupaten Kudus membutuhkan pendekatan ke semua pihak, baik dalam diri pemerintah atau Bupati Kudus harus dimasukkan dalam program pembangunan jangka panjang atau program jangka pendek, sehingga kebijakan tersebut bisa secepatnya direalisasikan dan pembangunannya secepatnya bisa dilaksanakan, karena City Walk adalah salah satu branding yang menaikkan citra sebuah Kota.

Demi menciptakan kualitas tata ruang kota maka Pemerintah Kabupaten Kudus mengeluarkan Peraturan Daerah Kabupaten Kudus Nomor 16 Tahun 2012 Tentang Rencana Tata Ruang Wilayah Kabupaten Kudus Tahun 2012 -2032.

Berlakunya peraturan daerah Kota Kudus tentang tata ruang dan wilayah membuat masyarakat dalam kehidupannya akan berjalan dengan tertib dan teratur bila ada tatanan, sedangkan tatanan dalam kehidupan manusia mempunyai sifat-sifat yang berlainan. Kehadiran hukum dalam masyarakat untuk mengintegrasikan dan mengkoordinasikan kepentingan-

\footnotetext{
${ }^{46}$ Nur Said, Spiritual Enterprenership Warisan Sunan Kudus : Modal Budaya Pengembangan Ekonomi Syari'ah Dalam Masyarakat Pesisir, STAIN Kudus, email : nursaid@ymail.com, hal 4
} 
kepentingan yang bisa berselisih satu sama lain, sehingga perselisihan itu bisa ditekan sekecil mungkin dengan aturan tata kelola kota khususnya mengenai city walk di area jalan Sunan Kudus, sehingga ada kejelasan peruntukannya oleh masyarakat.

Hambatan yang ditemui di lapangan adalah hambatan teknis dan hambatan non teknis. Hambatan teknis berkaitan dengan anggaran pemerintah untuk pembangunan City Walk harus diperjelas dan dipercepat agar rencana pembangunan City Walk cepat terealisasi. Hambatan non teknis berkaitan dengan parkir becak wisata, ojek wisata dan angkutan wisata dipindahkan ke utara pasucen, agar para penziarah memanfaatkan City Walk .

Sedangkan solusi yang dilakukan baik teknis mapun non teknis oleh pemerintah berupaya menganggarkan dalam APBD secara jelas dan menata kembali perdagangan yang menyangkut banyak pedagang kaki lima (PKL) dan tranportasi yang langsung maupun tidak langsung mempengaruhi proses pembangunan city walk.

\section{Kesimpulan}

Berdasarkan hasil penelitian dan pembahasan Kebijakan Mewujudkan Kota Kudus Sebagai City Walk (Kota Ramah Terhadap Pejalan Kaki), penulis menyimpulkan sebagai berikut:

1. Pemerintah Kabupaten Kudus membutuhkan pendekatan ke semua pihak, baik internal pemerintah atau Bupati Kudus harus memasukkan kebijakan tata kelola kota dalam program pembangunan jangka panjang atau program jangka pendek, karena City Walk adalah salah satu branding yang menaikkan citra sebuah Kota.

2. Hambatan yang ditemui di lapangan adalah hambatan teknis dan hambatan non teknis. Hambatan teknis berkaitan dengan anggaran pemerintah untuk pembangunan City Walk harus diperjelas agar terealisasi. Hambatan non teknis berkaitan dengan parkir becak wisata, ojek wisata dan angkutan wisata dipindahkan ke utara pasucen, agar peziarah memanfaatkan City Walk .

3. Solusi yang dilakukan yaitu pemerintah berupaya menganggarkan dalam APBD secara jelas dan menata kembali perdagangan yang menyangkut banyak pedagang kaki lima (PKL) dan tranportasi.

\section{Saran}

1. Pemerintah Kabupaten Kudus seharusnya mengatur dan memberikan payung hukum atau dasar hukum yang jelas untuk mengatur pembangunan City Walk di Kabupaten Kudus.

2. Pemerintah segera merencanakan dan menganggarkan dana untuk pembangunan City Walk dan anggaran perawatannya.

3. Pemerintah segera memasukkan City Walk perubahan peraturan daerah Kabupaten Kudus 20122032.

\section{DAFTAR PUSTAKA}

Anonim, Kajian Hukum Tentang City Walk, 2006.

Burhan Bungin, Metode Penelitian Sosial dan Ekonomi, PT. Fajar 
Inter Pratama Mandiri, Jakarta, 2001.

Imam Syaukani, Dasar-dasar Politik Hukum, PT.Raja Grafindo Persada, Jakarta, 2015.

Soerjono Soekanto, Pengantar Penelitian Hukum, Universitas Indonesia, Jakarta, 1986.

Khudzaifah Dimyati, Teorisasi Hukum Studi Tentang Perkembangan Pemikiran Hukum Indonesia 1945-1990, Genta Publising, Yogyakarta,2010.

Herdyanah Mustika, Peranserta Stakeholder Dalam Membentuk City Branding The Spirit Of Java Di Jalan Slamet Riyadi Surakarta, Jurnal Pembangunan Wilayah dan Kota, 2017.

Satjipta Raharjo, Ilmu Hukum, Citra Aditya Bakti, Bandung, 2012.

Natak Kristiono, Buku Ajar Otonomi Daerah, Jurusan Politik dan Kewarganegaraan, Fakultas Ilmu Sosial, Unnes semarang,2015.

Nana Abdul Aziz dkk, "Analisis Perencanaan Pembangunan Daaerah Dengan Pendekatan Sistem Lunak (Soft System) (Studi Pada Rencana Kerja Pembangunan Daerah (RKPD) Kota Malang.

Tim MIH Universitas Muria Kudus, Pedoman Penyusunan Tesis Magiter Ilmu Hukum Universitas Muria Kudus, Magister Ilmu Hukum, 2017.

\section{Peraturan Perundang-Undangan}

Undang-Undang Dasar NRI 1945

Undang-Undang Nomor 24 tahun 1992 tentang Penataan Ruang
Undang-Undang Nomor 4 tahun 1997 tentang Penyandang Cacat

Undang-Undang Nomor 38 Tahun 2004 tentang Jalan

Undang-Undang Republik Indonesia Nomor 25 Tahun 2004 tentang Sistem Perencanaan Pembangunan.

Undang-Undang Nomor 23 Tahun 2014 tentang Pemerintahan Daerah sebagaimana telah diubah beberapa kali, terakhir dengan Undang-Undang Nomor 9 Tahun 2015 tentang Perubahan Kedua Atas Undang-Undang Nomor 23 Tahun $2014 \quad$ tentang Pemerintahan Daerah

Peraturan Daerah Kabupaten Kudus Nomor 14 Tahun 2008 Tentang Organisasi dan Tata Kerja Dinas Daerah Kabupaten Kudus

Peraturan Daerah Kabupaten Kudus omor 16 Tahun 2012 Tentang rencana tata ruang wilayah kabupaten Kudus tahun 2012 2032.

Peraturan Menteri Dalam Negeri Nomor 54 Tahun 2010 Tentang Peraturan Pemerintah No.8 Tahun 2008 Tentang Tahapan Tatacara Penyusunan, Pengendalian Dan Evaluasi Pelaksanaan Rencana Pembangunan Daerah. 